\title{
Government Intervention and Farmers' Adaptation to Saline Intrusion: A Case Study in the Vietnamese Mekong Delta
}

\author{
Van Huynh Thanh Pham ${ }^{\#}$, Rudi Febriamansyah", ${ }^{*}$ Afrizal $^{1}$ and Thong Anh Tran ${ }^{2}$ \\ ${ }^{\#}$ Graduate Program at Andalas University, Padang Indonesia 25163, Indonesia; An Giang University, An Giang province 88000, Vietnam \\ Email:phtvan@gmail.com
}

*Faculty of Agriculture, Andalas University Padang, West Sumatra 25163, Indonesia; Email:_rfebriamansyah@agr.unand.ac.id

${ }^{I}$ Faculty of Social and Political Sciences, Andalas University, Padang, West Sumatra 25163, Indonesia; Email: afrizal@soc.unand.ac.id

\author{
${ }^{2}$ Asia Research Institute, National University of Singapore, AS8, Level 7, 10 Kent Ridge Crescent, Singapore, 119260; Research Center for \\ Rural Development, An Giang University, Long Xuyen city, An Giang province 88000, Vietnam \\ Email: thong.tran@nus.edu.sg.
}

\begin{abstract}
The Vietnamese Mekong Delta is located in the southern part of the country where the Mekong River runs through before it empties into the East Sea. Saline intrusion is a recurrent problem causing serious risks for agriculture and coastal livelihoods of the majority of people in the Delta. Collective adaptation plays an important role in improving the capacity of rural community to deal with environmental complexities. This research aims to examine how the collective adaptation supports the farmer and institutional adaptation to the conditions of saltwater intrusion in Tra Vinh and Kien Giang provinces. Statistical analysis was used to examine the trend of saltwater intrusion and the change in livelihoods of farmers in the Delta. The result shows the remarkable increase in salinity over the past twenty years. Various forms of adaptation were demonstrated by farmers' and governments' efforts in implementing adaptation practices to address salinity. Farmers have changed from rice to shrimp culture either through an intensive or extensive system where it is favorable to local environmental conditions. Meanwhile, local governments have attempted to establish various mechanisms to support collective actions (e.g., cooperative policies). The study highlights the critical role of formal and informal institutions that assist local adaptation processes. Adaptation practices were most pronounced in areas profoundly exposed to salinity impacts. The study suggests that further attention should be given to the establishment of institutional structures and rural social networks and how they are instrumental to collective adaptation.
\end{abstract}

Keywords - climate change; vietnamese mekong delta; saline intrusion; governmental intervention; collective adaptation; adaptive capacity.

\section{INTRODUCTION}

The Vietnamese Mekong Delta (VMD) is located in the south of Vietnam. It borders with Cambodia to the north, East Sea to the east and the Gulf of Thailand to the west. The Delta climate is tropical with two distinct dry and wet seasons. The wet season starts from June ( solar $^{1}$ calendar) through November giving almost rainfall to local regions. The rest of year is the dry season. As a vast wetland of four million hectares (ha), the VMD represents the excellent

\footnotetext{
${ }^{1}$ Solar calendar calculates months using the sun's movement while the lunar calendar bases on the moon.
}

potential for agricultural and aquacultural production. The Delta contributes to $54 \%$ of rice, $70 \%$ of aquaculture products and $37 \%$ of fruit [2]. It also provides a prodigious output for export including $90 \%$ of rice, $70 \%$ of aquaculture products and $60 \%$ of fruit [3].

Climate change and upstream hydropower construction have profound implications for the water resource system in the VMD [4]. These combined impacts cause saline intrusion (SI) taking place yearly in the dry season. It was the first time in 1998 that SI was at the extreme level [5]. It was realized that SI has occurred in higher density and magnitude [3], [6]. SI occurs when low river discharge flows to low-lying estuaries and when saltwater encroaches into the land [7], [8]. About 2.1 million ha of coastal areas are 
affected by salinity during the dry season [9]. It has adverse impacts on agriculture, aquaculture, and livelihoods of coastal people in the Delta [3], [10]. Adaptation to SI has been demonstrated in various forms, involving both farmers and local governments into collective efforts in response to changing environments. These adaptation practices are of significance in building effective collective responses, particularly in developing countries [11]. While collective adaptation to climate change has been widely understood in various development contexts, little has been known in coastal areas which are exposed to SI in the VMD. This research aims to understand situations of SI, the vulnerability and collective actions among fellow farmers and between farmers and local governments in responding to its impacts.

\section{MATERIAL AND METHOD}

\section{A. Research location}

Saline intrusion in the Delta is complex. The long coastline of the Delta with a density of canals and drainage systems allows salt water to intrude into many parts of the Delta [7], [8]. The greater part of the Delta is tidal, characterised by a mixed diurnal (the West) and semidiurnal (the East) effects [12], [13].

The stratified sampling approach was applied in this study [14]. This aims to stratify the sample by ecological zones. In this regard, Kien Giang (the West) and Tra Vinh (the East) provinces that represent the two sides of the coastal ecological zone in the Delta were selected (Fig.1). These provinces are adversely affected by SI over the past few years.

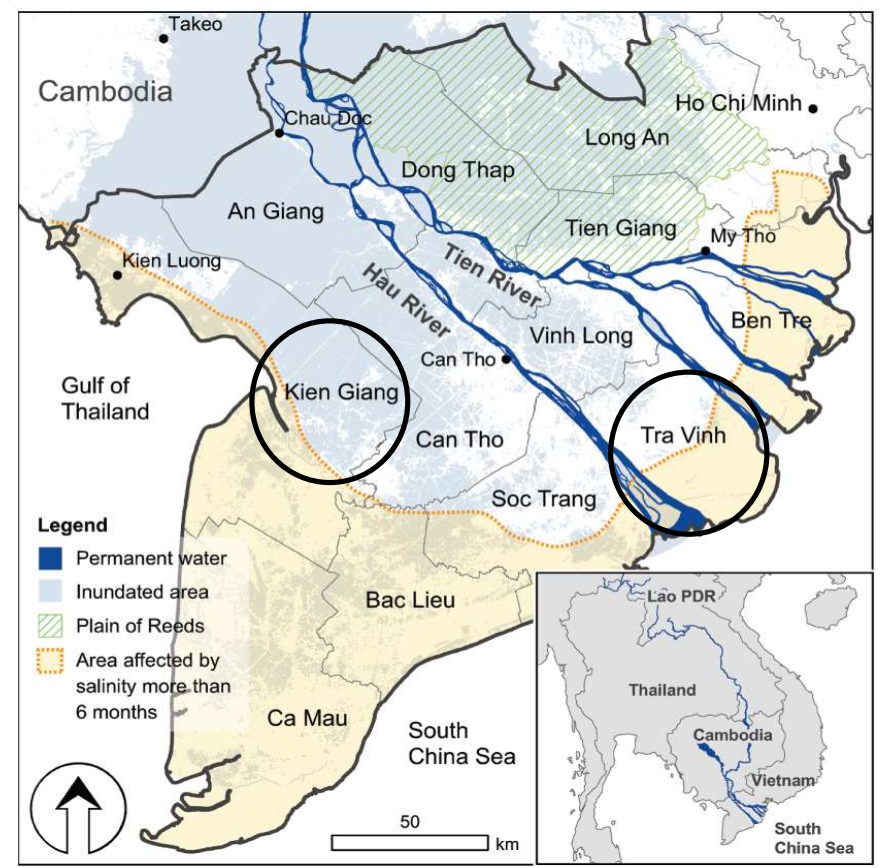

Fig 1. Areas affected by SI in the VMD and selected study sizes, Source: Mekong River Commission. 2005, adopted from [1]

Administered by Kien Giang and Tra Vinh provinces, An Bien and Cau Ngang districts were respectively selected as the study sites. These two districts are currently exposed to salinity, which is predicted to be more serious in the future.
In each district, two communes were selected, following the transect from the sea to inland, one near and one far the sea to see impacts of SI. They include Nam Yen and Dong Thai communes in An Bien district; Hiep My Dong and Vinh Kim communes in Cau Ngang district.

\section{B. Data collection and analyse}

The mixed-methods approach integrating both qualitative and quantitative data was applied in this research [15].

Primary data was gathered by collecting both qualitative and quantitative data. Firstly, a total of 16 meetings with key people at district, commune levels were undertaken to get information about SI conditions and its impacts. Surveys were administered to collect data of households' situation, vulnerability and forms of collective adaptation. The questionnaire was tested and revised before it was used widely. Totally, 280 questionnaires were conducted (70 questionnaires per commune). Interviewees are coastal farmers living in these areas for more than ten years.

Secondary data were collected to survey the trend of SI and salt concentration level provided by the Southern Institution of Water Resource Research. In particular, monthly highest data of salt concentration (January to May) from 2002 to 2017 were collected at Xeo Ro station (about 4 $\mathrm{km}$ from the West sea) and Ben Trai station (about $6 \mathrm{~km}$ far from the East sea).

Qualitative data were recorded, transcribed and categorized into themes. Various types of collective adaptation were identified. Data of salt level were calculated into yearly mean. Quantitative data was coded and analyzed using descriptive analysis, trend analysis to indicate change in farmers' livelihoods and collective adaptation in practice.

\section{RESULTS AND DISCUSSION}

\section{A. Saline intrusion in the Mekong Delta and vulnerability}

Saline intrusion occurs in the dry season, starting from December to May. However, it varies substantially due to being influenced by combined factors such as the Mekong river discharges, local rainfall and runoff, and tidal effects in the East Sea and the West Sea. This is not only attributed to weather conditions within Vietnam, but also wider global climate change and basin water resources developments [5]. Regarding salt concentration, SI occurs differently all over the Delta [6].

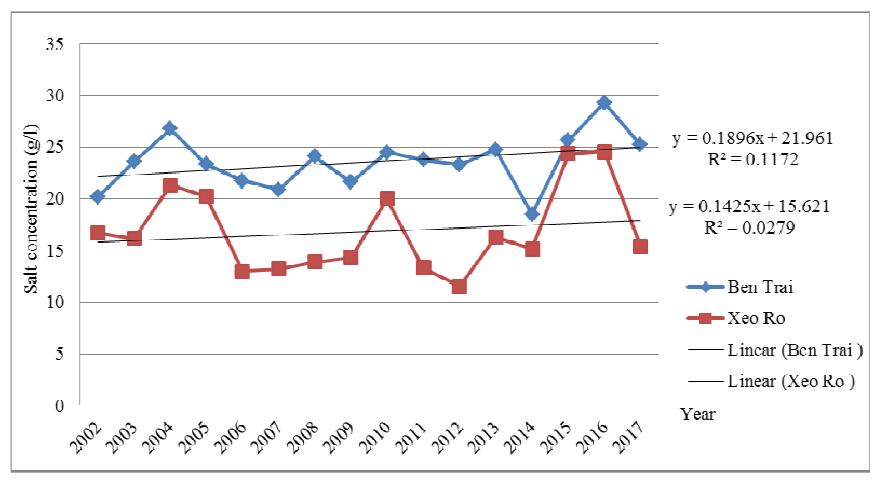

Fig 2: Saline intrusion increasing in the Mekong Delta from 2002 to 2017 (Source: Data collected from SIWRR (Southern Institution of Water Resource Research; Figure by the author) 
Data collected at Ben Trai, Xeo Ro stations suggested that salt level has increased in both sides of the Delta since 2002 (Fig.2.) Specifically, salt level in the West (Xeo Ro station) is lower than the East (Ben Trai station) because of tidal effects. The Delta is influenced by two types of tides that have significant implications for SI. The East is strongly influenced by irregular semi-diurnal tides (two high and two low tides of about equal size on every lunar day) with large tide amplitude of 3.0-4.0 m. In the West, tides are diurnally irregular (having one high and one low tide on every lunar day) with a tidal range of about 0.8-1.2 $\mathrm{m}$ [12], [13].

Saline intrusion is seen as a risk, exposed by not only increasing salt level but also its uncertainty. It causes severe impacts on livelihoods of coastal and inland people. Inland areas not previously facing annual brackish or salt water in the dry season are more severely affected than coastal areas [16]. The cost is substantial if it is calculated at once. For example, according to a reported by Minister Agriculture and Rural Development (MARD), the SI incidence in April of 2016 destroyed 208,000 ha of rice (more than $70 \%$ of yield loss), 9400 ha of fruit trees and 2000 ha of aquaculture lost in April of 2016 [3]. The total damage across all sectors was calculated up to 360 million USD [17]. The reason was that inland people did not have experience in dealing with SI. When it happened suddenly, they did not know how to respond. The event that hit the VMD in 2016 was seen as the 100-year record in the Delta [10].

Coastal farmers were vulnerable to SI as much as their counterparts in the inland areas. Strategically, they have changed their livelihoods little by little to adapt. $67.90 \%$ of farmers in the West and $86.70 \%$ in the East mentioned that $\mathrm{SI}$ is uncertain. Forecast systems can inform current status, but hardly predict future situations due to a number of complicated reasons. Local people did not know how to manage their crops. They reacted passively to SI, both current and future conditions.

Both inland and coastal inhabitants are vulnerable to SI. As noted by informants living in inland areas, saltwater level penetrated into protected areas, which caused significant damage to crops grown inside. In 1990s, the Government invested such salinity control projects as Go Cong, South Mang Thit, Quan Lo Phung Hiep and Ba Lai systems to control an region about 926,000 ha with 650,000 ha devoted to agricultural production [18], [19]. Qualitative analysis suggested that coastal farmers found it difficult to make suitable decisions (e.g., types of crop, investment capital...) or apply change in techniques, crop calendar to deal with the situation to guarantee their income during the dry season.

The dry and the wet season cannot be distinct as they were in the past. The wet season comes late causing SI. Rice cannot be grown on time following the regional season calendar (Group discussion (2017), Nam Yen Commune, An Bien District, Kien Giang province).

If the dry season comes late, salt remains at low level and shrimp crops cannot start. Farmers have to wait. The crop starts one or two months later than the normal years (Key informant interview (2018), Hiep My Dong Commune, Cau Ngang District, Tra Vinh province).

\section{B. Changing of farming systems as an adaptation}

Rice is the main product in the VMD, accounting for $50 \%$ of the whole national production [3]. Since 2000 rice areas had been reduced in the coastal areas, which was due to three main reasons. The first was associated with the SI impacts. Rice cannot be planted because it is intolerant to salinity in the soil and water beyond $4 \mathrm{~g} / \mathrm{l}$ [7], [12]. As a result, shrimp was used to replace. The second was attributed to the release of the Government's document No. 09/NQ-CP that allowed farmers to change land use policy from rice culture to shrimp culture in infertile coastal areas. The fact that Viet Nam joined WTO (World Trade Organisation) in 1997 and greater access to the technical assistance enabled farmers to shift from rice culture to shrimp business.

Fig. 3 showed that shrimp areas on the West and the East have increased rapidly since 2006 while rice areas got declined. In the Eastern side, shrimp areas increased slower than in the western part due to farm size's demand of different shrimp systems. Extensive system needs larger areas than intensive shrimp. Rice areas in An Bien district went down steeply since they were devoted to shrimp culture. Rice was not fully harvested due to the unexpected intrusion of salinity. In 2016, in An Bien district there were 3000 ha of rice areas were not harvested [20].

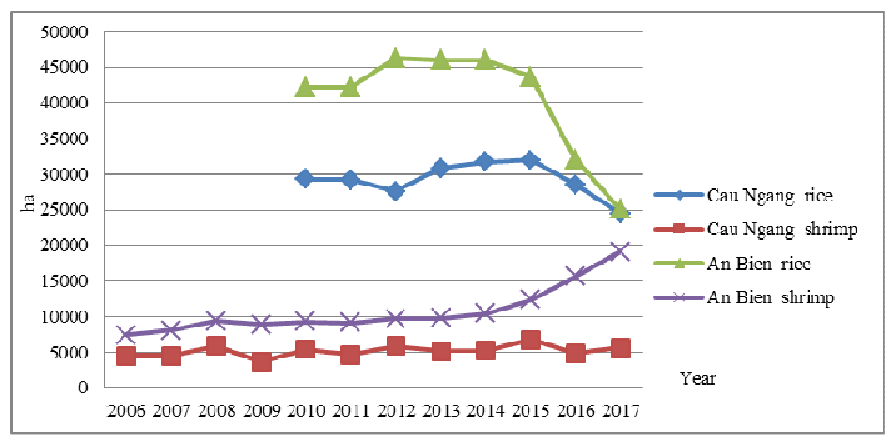

Fig 3: Harvested shrimp and rice areas in An Bien and Cau Ngang districts from 2006 to 2017

(Source: Data collected from Agriculture and Rural Development Department in Cau Ngang and An Bien districts, District Statistic Books; Figure by the author)

Adaptation to environmental change is not a new phenomenon. They have been long practiced in human history [11], [21]-[24], and it is highly context specific [25][27]. Data collected from household survey suggested that most farmers in both regions have shifted from rice culture to shrimp culture since 2000. However, types of shrimp system were seen different from the West and the East. In An Bien district, the integrated shrimp-rice system (extensive farming) was dominant $(99.33 \%)$ while farming systems were more diversified including both intensive and extensive shrimp systems in Cau Ngang district. Intensive shrimp ( 2 crops of shrimp per year or more) was the most popular system $(62.14 \%)$, and the second one was shrimp rice system (35.53\%). 
TABLE I

Changing From Rice Culture To Shrimp Culture In Kien Giang AND TRA VinH PROVINCES SinCE 2000

\begin{tabular}{|c|l|c|c|c|c|}
\hline \multirow{2}{*}{ Farming system } & \multicolumn{2}{c|}{ Tra Vinh } & \multicolumn{2}{c|}{ Kien Giang } \\
\cline { 2 - 6 } & Freq.* & $(\%)$ & Freq.* & $(\%)$ \\
\hline 1 & $\begin{array}{l}\text { One rice to shrimp - } \\
\text { rice }\end{array}$ & 5 & 3.33 & 34 & 23.99 \\
\hline 2 & $\begin{array}{l}\text { Two rice to shrimp - } \\
\text { rice }\end{array}$ & 134 & 96.00 & 16 & 11.54 \\
\hline 3 & $\begin{array}{l}\text { One rice to intensive } \\
\text { shrimp }\end{array}$ & - & - & 65 & 46.19 \\
\hline 4 & $\begin{array}{l}\text { Shrimp - rice to } \\
\text { intensive shrimp }\end{array}$ & 1 & 0.68 & 22 & 15.95 \\
\hline 5 & $\begin{array}{l}\text { Others (upland, animal, } \\
\text { fruit....) }\end{array}$ & - & - & 3 & 2.35 \\
\hline \multicolumn{2}{|l|}{ Total } & 140 & 100 & 140 & 100.00 \\
\hline
\end{tabular}

(*) Frequency - (Source: Household interview, 2018); $(\mathrm{n}=280)$

In the West, integrated shrimp rice system is shrimp culture using saline water in the dry season followed by rice culture depending on rainwater in the wet season. The shrimp crop starts in December or January depending on yearly seasonal calendar stipulated by the Office of Agriculture and Rural Development. In this system, back tiger shrimp (Penaeus monodon) is raised because they require less or no food. In case the salt is not high enough, farmers replace back tiger shrimp with giant freshwater prawn (Macrobrachium rosenbergii) or fish to maintain income. Freshwater giant prawn grows well in the lower level of salt water (from $4-6 \mathrm{~g} / \mathrm{l}$ ) while back tiger shrimp requires with the salt water level from $15-20 \mathrm{~g} / \mathrm{l}$. These suggested that drawing on their experiential knowledge; farmers become more flexible in responding to climate risk (Fig. 4).

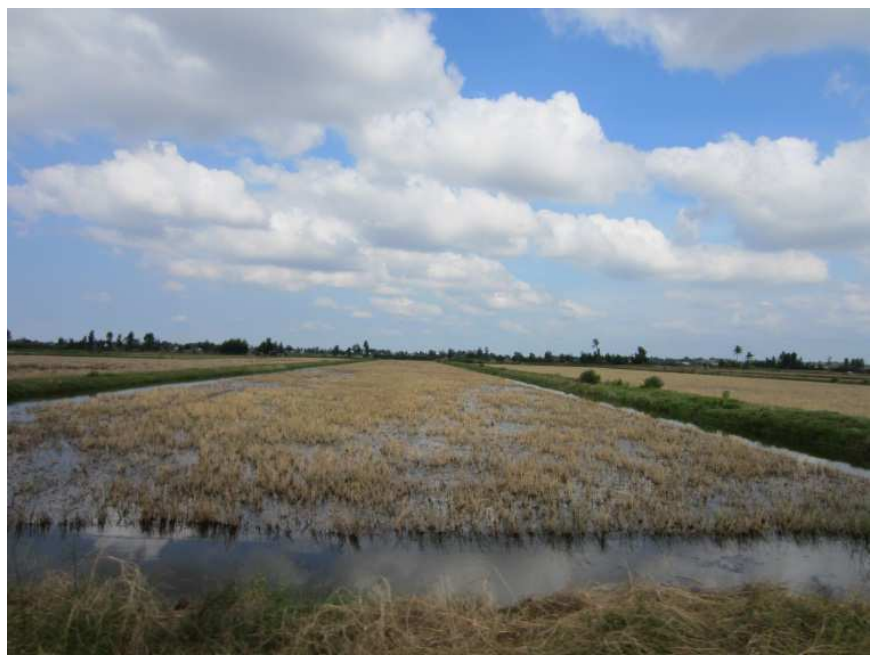

Fig 4: Wide adoption of the shrimp-rice system in Nam Yen commune, An Bien district, Kien Giang province

(Source: the author, 2018)

There are three main reasons that explain the differences of shrimp farming typologies in the two areas:

Farm size is the first. To apply the shrimp rice system, farm size has to be large enough. About $25-30 \%$ of field surface is transferred to be trenches. The average farm size per household in the West is larger than that in the East (An
Bien: 1.88 ha/household; Cau Ngang 0.93 ha/household) compared with 1.15 ha for the VMD and 0.72 ha in Vietnam as a whole [27] adapted from [28]. In addition, farmers are interested in various faming typologies. Most farmers in the West consider shrimp rice system as a sustainable model which brings more sources of income and creates an environment-friendly farming practice. Farmers can earn money twice a month from shrimp when tide is high (15th and 30th in Lunar calendar). It is better than waiting for three months to get money from rice crop.

In the East, it was evidenced that farmers by applying the intensive system could earn great profits if the model was successful. It is a huge amount of money. This explained why before 2008, farmers mainly cultured Back Tiger shrimp. However, now White Leg shrimp (Litopenaeus vannamei) is dominantly practiced because they can live in higher density and are cultured in short duration.

The last reason was linked to farmers' decision in selecting shrimp farming systems. The selection is attributed to the aging factor. Evidence suggested that old farmers (above 50 years old) tended to keep shrimp rice system while young counterparts were more inclined to intensive shrimp rice system because it brings greater benefit (Fig. 5). It also indicated that young farmers were more willing to take risks.

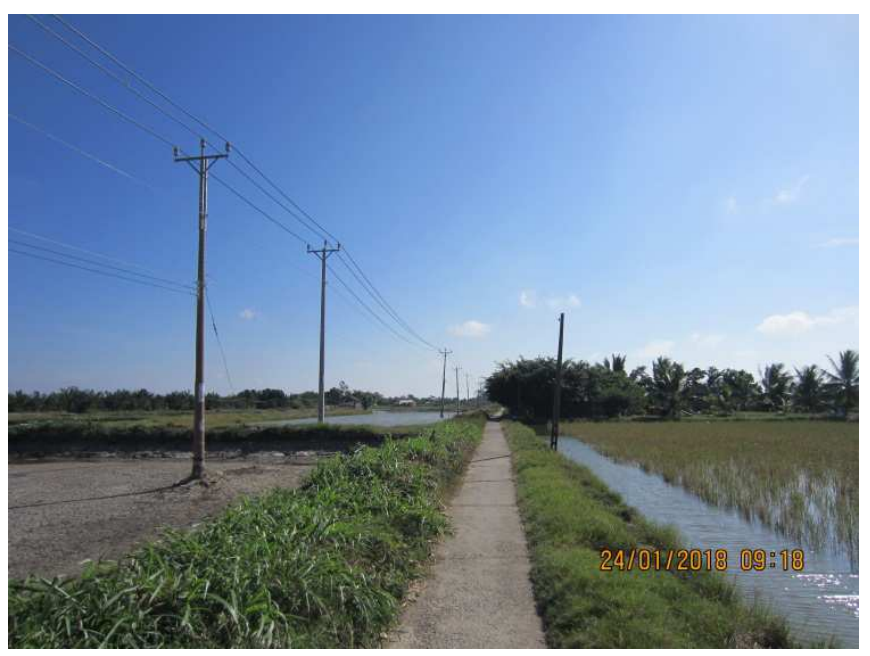

Fig. 5: Diversified shrimp farming systems in Hiep My Dong commune, Cau Ngang district, Tra Vinh province. Intensive shrimp farming on the left and the integrated shrimp-rice system on the right

(Source: the author, 2018)

\section{Government efforts to support collective adaptation}

Adaptation can be found in various forms, including taking action by an individual, group and institution in response to the impacts of climate change [24], [29]. Working together is an appropriate way to build adaptive group capacity. Worldwide, it is clear that collective action helps to build successful adaptation. It plays a vital role in decision-making processes in natural resources management [11], [30, [31]. In terms of adaptation, collective actions may take many forms, including the development of institutions, resource mobilization, coordination of activities, and information sharing [32]. The results showed that two forms of collective adaptation in case of SI were found. They included coordinative activities and information sharing. 146 
households $(52.14 \%)$ participated in social organizations ${ }^{2}$. For instance, in 2017, 15 co-operations and over 100 groups in An Bien district were established. Meanwhile, 7 cooperation and 310 groups in Cau Ngang district involved in various agricultural sectors such as rice, shrimp, upland and agricultural services [33], [34].

Reference [35] mentioned a list of actions that can be seen as collective actions in the Delta. They included sharing knowledge through sowing seed at the same time, protecting dikes, and cooperating to meet market demand. Those actions were based on the relationships (social capital) among groups or among farmers or cooperation between the government officials and farmers. So, it is vital to understand because how well social capital can be acted depending on the interactions among its nature, government structure, an institution [19]. Currently, supporting farmers to work in a group is one of the political strategies. In Vietnam, there are two forms of organizations: the formal and the informal. The formal organizations are aligned with the Vietnamese political system ${ }^{3}$. They represent different groups of people's right and benefits [36]. The result indicated that formal organizations exist in almost research areas. Farmer Union and Woman Union contribute mainly to supporting the local government to develop rural livelihoods. Cooperation and shrimp group are those organizations that directly build collective actions among members in case of SI. More farmers joined those activities after they were affected by SI (Table II).

TABLE II

ORGANISATIONS FARMERS INVOLVED

\begin{tabular}{|c|l|l|l|l|l|}
\hline \multicolumn{2}{|c|}{} & \multicolumn{2}{c|}{ An Bien } & \multicolumn{2}{c|}{ Cau Ngang } \\
\hline \multicolumn{2}{|c|}{ Formal organization } & Freq.* & $(\%)$ & Freq.* & $(\%)$ \\
\hline 2 & Farmer union & 19 & 31.15 & 18 & 17.31 \\
\hline 3 & Woman union & 21 & 34.43 & 33 & 31.73 \\
\hline 4 & Shrimp cooperation & 8 & 13.11 & 15 & 14.42 \\
\hline 5 & $\begin{array}{l}\text { Shrimp group } \\
\text { gorrowing money }\end{array}$ & - & - & 22 & 21.15 \\
\hline 6 & $\begin{array}{l}\text { Others (Red cross, } \\
\text { Elder union...) }\end{array}$ & 2 & 3.28 & 9 & 8.65 \\
\hline \multicolumn{2}{|c|}{ Total } & 61 & 100.00 & 104 & 100.00 \\
\hline Informal organization & \multicolumn{4}{|l|}{} \\
\hline 1 & Lending money (Hui) & 4 & 15.38 & 3 & 21.43 \\
\hline 2 & Religious group & 7 & 26.92 & 1 & 7.14 \\
\hline 3 & Exchanging labour & 2 & 7.69 & 5 & 35.71 \\
\hline 4 & $\begin{array}{l}\text { Exchanging } \\
\text { experience }\end{array}$ & 9 & 34.62 & - & - \\
\hline 5 & $\begin{array}{l}\text { Water management } \\
\text { group }\end{array}$ & 4 & 15.38 & - & - \\
\hline
\end{tabular}

2 There are two types of organizations in the current Vietnamese system: political and social organization. This study does not mention political organizations that include Communist Party, Youth Union

3 There are three parts in the political structure; Communist Party; the Government and social and political organization. Communist Party leads, the Government manages and the organization represents for the people's right. The three parts have different roles and closed relation to form the united of Vietnamese political structure

\begin{tabular}{|c|l|l|l|l|l|}
\hline 6 & $\begin{array}{l}\text { Labour group (for } \\
\text { renting) }\end{array}$ & - & - & 5 & 35.71 \\
\hline Total & 26 & 100.00 & 14 & 100.00 \\
\hline
\end{tabular}

(*): Frequency; (Source: Household interview, 2018); $(\mathrm{n}=146)$

Working in the group brings a lot of benefits to local people such as managing water resource, buying good quality of postlarval shrimp; or exchanging experience and technique. Those benefits cannot be achieved by farmers' action alone. Collective action helps to improve adaptive capacity especially in case of having intervention from the Government. It is likely more productive for policy interventions to focus on improvements in the adaptive capacity of disadvantaged rural populations [20]. The Government built such strategies to support. Co-operation (Hop tac $x a$ ), a collective economic group, acts under the cooperation law. The law was established in 1996 and adjusted in 2003, 2012 and 2016 to suit the current situation. Collective group (To hop tac) is based on the 151/2010/NĐCP dated 10/10/2010 of the Prime Minister, stipulating "organizing an act of group" as a collective economic group. It is smaller than cooperation in working scale and responsibility. Both of them are considered as common economic groups. In reality, they work not only to achieve economic purpose but also for environmental and social aims. It supports farmers to earn a high profit, to get environmental protection and maintain social relationships among members in the groups.

Informal organizations are slightly different from the West and the East. Lending money group (Hui) ${ }^{4}$ exists in two areas. It is an informal and favorite type of money lending in Vietnamese rural communities. Currently, it is guided under edict 144/2006/NĐ-CP dated 27/01/2006. Religious groups work mostly in charity and old people take part in this group. Labour exchange (Van cong) is found to be more popular in Tra Vinh as they do the same system: they can help each other during crop harvesting season.

For the informal organizations linked to SI adaptation, they are classified into sharing information activity form. Exchanging experience group and water management group was only found in An Bien district that helped local farmers to manage water resource. Shrimp rice farmers in An Bien district communicated to others to make effective use of water resources which are uncertain under the change in the onset of the rainy season and the rainfall [37]. The formal organization follows the governmental instruction while informal organizations were more related to farmers' actions. For each form, they build their own rules in accordance with the Vietnamese law [38].

The two case studies below describe how formal and informal organizations worked in research areas.

Case study 1: Doan Ket shrimp group in Hiep My Dong commune, Cau Ngang district, Tra Vinh province - the formal organization

\footnotetext{
4 "Hui" is a group of people who can lend money to others with interest rate based on the group decision. The interested rate is decided for every time period (a week; a moth; every 2 month...). People who want to get money. They have to give high rate of interest. The money will be given to person offering the highest interest rate.
} 
Hiep My Dong Commune People Committee formed Doan Ket, intensive shrimp group in January 2017. There are 34 members with a total land area of about 11.3 ha of water surface devoted to shrimp culture. Regarding to be a member of this group, three conditions need to be met, including:

(1) Member has to use the services of the group;

(2) Member takes part in money sharing activity;

(3) Member has to be a member of Farmers Union.

Members in the group follow one process of raising shrimp including using same source of post larval shrimp, applying the same techniques and using only biochemical. Meeting is hold monthly at 12 a.m. on $29^{\text {th }}$ (Lunar calendar) at the house of the group leader. During the meeting, members discuss what have been done this month and also make plan for next month; exchange experience and solve problems faced by group members. Farmers can also earn additional benefit. They buy postlarval shrimp with a cheaper price (the head of group contacts the company to get the deal). Usually, they get $10 \mathrm{VND}$ less per post-larval shrimp (5 VND is given back to farmers, and the rest is given to the group's budget using for group activities). To be member of this group, farmers can get higher profits, technical advice and practice farming in safe farm conditions.

Case study 2: Shrimp rice farmer exchanging experience group in Nam Yen commune, An Bien district, Kien Giang province - informal organization

There is a group that includes 20 shrimp rice farmers. They have regular meeting at house of Mr. T. He is a 63 years old man, a very knowledgeable farmer. Other farmers wish to come and attend the meeting because they believe that $\mathrm{Mr}$ can give them appropriate information and techniques. Every day at 10 a.m., after having lunch at home, farmers come to his house to have tea, to play chess and to talk with other members. Sometimes, Mr. T discussed with the company to buy postlarval shrimp on his friend behalf for cheaper price. The group has operated more than three years, and it still functions well and attracts more farmers to join the group. The model is good, and it can be seen as an exemplary model for other places to learn and follow the practice. One thing should be noted here that to maintain group well, the leader needs to have charisma and capacity to manage the group.

\section{Issues for future research}

In terms of cooperative activities, social relationships are an essential factor that can explain how individuals can work together in groups. It can be a reason to explain why the organization exists in one area but not in others; and how the free -rider problem could be avoided. If everyone chooses the free-rider, the collective benefit will not be produced [39]. In fact, social capital and institutional system support the implementation of collective adaptation and ways to make it more effective. The study indicated that organizations occur in different frequency and extensively. Those formal and informal organizations linked to related SI adaptation only exist in areas locating near the sea on both

\footnotetext{
5 One member gives 50,000 VND per month to a member who needs it at this time. The same process gives to another one in the following month.
}

the West and the East. These areas have been faced to SI for a longer time. The role of social network and the institutional system should be explored in future research. They provide insights into the use of social capital and collective actions to adapt to the risk exposed by climate change.

\section{CONCLUSIONS}

The saline intrusion was realized as climate risk that adversely affected the livelihoods of coastal people in the VMD. It exposed not only in terms of intensity but also uncertainty. The study suggested the tremendous impacts of SI on both sides of the Delta. Both local governments and farmers have implemented adaptation in different ways. Shifting farming system was the primary practice to minimize the impacts of SI. The interaction between the Governmental and farmers' help improve local adaptive capacity. Collective adaptations were demonstrated in two forms: cooperative activities and sharing information. Both formal and informal organizations associated with responses to SI were found in the areas in the vicinity of the sea that experienced longer duration and more significant impacts of SI. Future study should give more attention to how social network and institutional systems support social capital on the ground. It gives an understanding to what extent the collective adaptation could be implemented effectively to contribute to the enhancement of rural adaptive capacity.

\section{ACKNOWLEDGMENT}

We would like to express our thankfulness to PEERUSAID for giving us a research grant for this study.

\section{REFERENCES}

[1] Käkönen, M., Mekong Delta at the Crossroads: More Control or Adaptation? AMBIO: A Journal of the Human Environment, 2008. 37(3): p. 205-212.

[2] MARD (Ministry of Agriculture and Rural Development), Solutions for changing agriculture system in regions in the Mekong Delta. Conference of Sustainable and Climate Resilience Development of the Mekong Delta of Vietnam 2017: Can Tho.

[3] IPSARD (Instituition of Policy and Strategy for Agriculture and Rural Development), Drought and saline intrusion in the Mekong Delta - Adaptations from rice farmers, local goverment and solutions 2016: Ha Noi

[4] MARD (Ministry of Agriculture and Rural Development) and MONRE (Ministry of Natural Resources and Environment), Mekong Delta plan - Long-term vision and strategy for a safe, prosperous and sustainable delta. 2013: Ha Noi

[5] Dang, K.N., V.B. Nguyen, and H.T. Nguyen, Water use and competition in the Mekong Delta, Vietnam. Challenges to sustainable development in the Mekong Delta: regional and national policy issues and research needs. The Sustainable Mekong Research Network, 2007: p. 143-188.

[6] SIWRR (Southern Institute of Water Resources Research), Saline intrusion status in the Mekong Delta report. 2015, Southern Institute of Water Resources Research: Ho Chi Minh

[7] Le, A.T., et al., Flood and salinity management in the Mekong Delta, Vietnam. 2007.

[8] Pedro Estellès, et al., Sustainable Development in the Mekong Delta. AMBIO: A Journal of the Human Environment. 2012, University of Aarhus, Denmark: Center for Environmental Studies. .

[9] WB (World Bank), Building resilience in the Mekong Delta Technical Report to Support the Rapid Environment Assessment. 2015, World Bank Viet Nam. 
[10] Nguyen, C.T., Saltwater Intrusion - An Evident Impact of Climate Change in the Mekong Delta and Propose Adaptable Solutions. American Journal of Environmental and Resource Economics, 2016. Vol. 1, No. 1 .

[11] Adger, W.N., Social capital, collective action, and adaptation to climate change, in Der klimawandel. 2003, Springer. p. 327-345.

[12] Nguyen, A.D., Salt intrusion, tides and mixing in multi-channel estuaries. 2008, PhD Thesis, UNESCO-IHE Institute for Water Education, Delft, The Netherlands.

[13] Vo, K.T., Hydrology and hydraulic infrastructure systems in the Mekong Delta, Vietnam, in The Mekong Delta System. 2012, Springer. p. 49-81.

[14] Vaus, D.A.d., Surveys in Social research, ed. 1985, 1991, 1995, 2002 2002, Australia: SRM Production Services Sdn Bhd, Malaysia.

[15] Miller, F., et al., Resilience and vulnerability: complementary or conflicting concepts? Ecology and Society, 2010. 15(3).

[16] Van, P.D.T. and T.P.M. Vo, Impacts of local hydrological changes on land use changes in Cau ke, Tieu Can and Cau Ngang districts in Tra Vinh Province Can Tho scientific journal 2013. 25(Part A: Natural Science, technology and environment ): p. 59-67.

[17] Nguyen, N.A., Historic drought and salinity intrusion in the Mekong Delta in 2016: Lessons learned and response solutions. Vietnam Science and Technology, 2017. 1(1): p. 93-96.

[18] Tran, H.D. To find out irrigation solutions for the Mekong Delta of Vietnam. 2009 [cited 2018 20/02/2018]; Available from: http://www.khoahoc.net/.

[19] Nguyen, T.M.P., Saline intrusion in the Mekong delta: Causes, impacts and adaptive solutions 2016, Minister of Science and Techology Natital department of Science information and Technology

[20] Agrawal, A. and N. Perrin, Climate adaptation, local institutions and rural livelihoods. Adapting to climate change: thresholds, values, governance, 2009: p. 350-367.

[21] IPCC (Intergovernmental Panel on Climate Change), Working Group II: Overviews of Impacts, Adaptation and Vulnerability to climate change 2001 .

[22] Marwell, G., P.E. Oliver, and R. Prahl, Social networks and collective action: A theory of the critical mass. III. American Journal of Sociology, 1988. 94(3): p. 502-534.

[23] Adger, W.N., et al., Adaptation to climate change in the developing world. Progress in development studies, 2003. 3(3): p. 179-195.

[24] Bowyer, P., et al., Adapting to Climate Change: Methods and Tools for Climate Risk Management. Climate Service Center, Germany, 2014. 124.

[25] Burton, I., E. Diringer, and J. Smith, Adaptation to climate change: international policy options. 2006: Citeseer.
[26] Agrawal, A., Local institutions and adaptation to climate change. Social Dimensions of Climate Change. Equity and Vulnerability in a Warming World. R. Mearns (ed.), 2010: p. 173-198.

[27] Hossain, M., T. Ut, and M. Bose, Livelihood systems and dynamics of poverty in a coastal province of Vietnam. Environment and Livelihoods in Tropical Coastal Zones: Managing AgricultureFishery-Aquaculture Conflicts. CAB International, Wallingford, UK, 2006: p. 30- 47.

[28] Nguyen, D.C., et al., Livelihoods and resource use strategies of farmers in the Mekong Delta. Challenges to sustainable development in the Mekong delta: regional and national policy issues and research needs. The Sustainable Mekong Research Network, Bangkok, 2007: p. 69-98.

[29] Pielke, R.A., Rethinking the role of adaptation in climate policy. Global Environmental Change, 1998. 8(2): p. 159-170.

[30] Ostrom, E., Ostrom, E. 1990. Governing the Commons: The Evolution of Institutions for Collective Action. 1990, Cambridge University Press.

[31] Groot, A. and M. Maarleveld, Demystifying facilitation in participatory development. 2000: IIED.

[32] Poteete, A.R.O., Elinor, In pursuit of comparable concepts and data about collective action. Agricultural Systems, 2004. 82(3): p. 215232.

[33] Department of Agriculture and Rural Development, Report for end of year and strategy for next year 2010 - 2016: Cau Ngang district, Tra Vinh province

[34] An Bien Department of Agriculture and Rural Development, Report for end - year summation 2016 and strategy for 2017. 2016: An Bien district, Kien Giang province.

[35] Vo, V.T., et al., The farmers' capacity to adapt with climate change in the Mekong Delta. Can Tho University Scientific journal 2014. Part D (31)(Political Science, economic and law ): p. 63-72.

[36] Hoang, C. B. (2005). Political system in rural areas in Vietnam currently. Ha Noi, Political Argument Publishing House

[37] Pham, H.T.V. and R. Febriamansyah, Explore forms and factors affecting collective adaptation to salt water intrusion in the Mekong delta of Vietnam, in The XVI Biennial IASC Conference Practicing the commons: self-governance, cooperation, and institutional change. 2017: Utrecht University, The Netherlands

[38] Ngo, T.P.L., From rice to shrimp, action to reduce risk and use of social capital in the Vietnamese Mekong Delta. Ho Chi Minh City Publishing House. 2014.

[39] Ostrom, E., Background on the institutional analysis and development framework. Policy Studies Journal, 2011. 39 (1): p. 727. 